\begin{tabular}{|c|c|c|}
\hline \multirow[b]{2}{*}{ 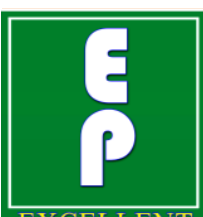 } & $\begin{array}{l}\text { International Journal of Current Research in } \\
\text { Biosciences and Plant Biology }\end{array}$ & \\
\hline & Volume $7 \bullet$ Number 1 (January-2020) • ISSN: 2349-8080 (Online) & \\
\hline $\begin{array}{l}\text { PABLISHERS } \\
\text { PUBLE }\end{array}$ & Journal homepage: $\underline{w w w . i j c r b p . c o m}$ & \\
\hline
\end{tabular}

\title{
Influence of salinity on the incidence and severity of Phytophthora megakarya in a hybrid family of Theobroma cacao $\mathrm{L}$.
}

\author{
C. Simo ${ }^{1,3 *}$, I. A. V.Tchiaze ${ }^{1}$, E. N. Tchouakeu ${ }^{1}$, S. A. Njonzo-nzo, S. D. Tassong1, \\ P. F. Djocgoue ${ }^{2,3}$, N. Niemenak3 and V. D. Taffouo ${ }^{1}$
}

\author{
${ }^{1}$ Department of Plant Biology, Faculty of Science, University of Douala, Cameroon \\ 2Department of Plant Biology, Faculty of Science, University of Yaoundé 1, Cameroon \\ 3Laboratory of Plant Physiology, Department of Biological Sciences, Higher Teacher's Training College, \\ University of Yaoundé 1, Cameroon \\ *Corresponding author; e-mail: simoclaude@yahoo.fr / simoclaude@univ-douala.com \\ Phone: (+237) $677589287 / 691783607$
}

\begin{tabular}{|c|c|}
\hline Article Info & ABSTRACT \\
\hline $\begin{array}{l}\text { Date of Acceptance: } \\
28 \text { December } 2019\end{array}$ & \multirow{3}{*}{$\begin{array}{l}\text { Diseases and abiotic stresses constitute the main constraints in the production of cocoa } \\
\text { (Theobroma cacao) in coastal regions. To this end, the use of productive and resistant } \\
\text { or tolerant hybrid genotypes is an alternative for improving its production in these } \\
\text { regions. In order to select new hybrid genotypes tolerant to Phytophthora megakarya } \\
\text { under sodium and saline stress at different concentrations, the incidence and severity of } \\
\text { this pathogen were evaluated through the evaluation of the development of necrosis } \\
\text { after infection in the parental genotypes SNK413 and T79 / 501 and in their } \\
\text { descendants (F79SB: SNK413xT79 / 501) under conditions of saline stress. Date and } \\
\text { hybrid genotype effects were found to be significant (P <0.05) during necrotic } \\
\text { development. Under saline conditions at different concentrations, the size of the } \\
\text { necrotic surfaces was a function of the values of the different concentrations used. It } \\
\text { has been observed that the higher the salt concentrations, the larger the necrotic } \\
\text { surfaces. These results suggest that salinity increases the sensitivity of cocoa to } \\
\text { Phytophthora megakarya. The hybrid genotypes F79SB3, F79SB4, F79SB5, F79SB8 } \\
\text { and F79SB15 were distinguished by small necrotic surfaces whatever the saline } \\
\text { concentration used. These hybrid genotypes could therefore be used in a breeding } \\
\text { program in regions with a high salt concentration in order to improve yields in cocoa } \\
\text { plantations. }\end{array}$} \\
\hline Keywords & \\
\hline $\begin{array}{l}\text { Hybrid gen } \\
\text { Phytophth } \\
\text { Salinity } \\
\text { Theobrom } \\
\text { Tolerance }\end{array}$ & \\
\hline
\end{tabular}

\section{Introduction}

The cocoa tree (Theobroma cacao L.) is native to the tropical rain forests of Central and South America (Janny et al., 2003; Pokou et al., 2019). The cultivation of cocoa plays a major role in the economy of the main African cocoa producing countries where this cultivation provides foreign currency to the country, contributes to the state budget and provides an income to the rural populations who live on it (Koudjega and Tossah, 2009; Anushka and Dunwell, 2018; Morrissey et al., 2019). However, cocoa cultivation faces many pest attacks that are the source of many diseases (Ploetz, 2007). Pathogens can destroy the entire production when conditions are favorable for the disease. 
In Cameroon, Phytophthora megakarya is recognized as the most aggressive pathogen. This pathogen is responsible for the highest production losses in cocoa plantations (Nyassé, 1997). These losses can reach 90 to $100 \%$ depending on the region, genotype, environmental conditions and in the absence of phytosanitary treatments (Ndounbe-Nkeng et al., 2004; Nyadanu et al., 2012). Chemical control against this parasitic attack, although effective, is expensive and poses the problem of toxicity for the famers. In addition to attacks by different organisms (insects, and microorganisms), the biotope does not always offer favorable conditions for the development of the plant. In this natural environment, the plant is forced to face various stresses such as the salt stress which the soils of the coastal regions face.

In the coastal regions of Cameroon the cocoa tree is cultivated on salty soils which cover large areas. These cultural practices would pose the problem of its adaptation to salinity for its extension in cultivated areas. Soil salinity is a major abiotic constraint which negatively affects the physiological aspects of the plant, leading to a reduction in its yield (Ruiz-Lazano et al., 2012; Almeida et al., 2014). In addition, it induces osmotic stress, physiological dryness and ionic imbalance, thus deactivating the vital cellular functions and weakened the tolerance level of the plant (Djerroudi et al., 2011; Taffouo et al., 2013; Gupta and huang, 2014). This constraint leads to a drop in water availability, reduces the rate of respiration (Cramer et al., 2013), the distribution of mineral salts (Babu et al., 2012) and variations in turgor pressure (Shabala and Munns, 2012). Plants therefore trigger hormonal, physiological and biochemical mechanisms either by tolerating or by resisting this constraint (Almeida et al., 2014; Erashan et al., 2015).

In addition, the reduction in growth due to salinity is also attributable to the toxicity of the ions and the nutritional imbalance. This state not only leads to an increase in the accumulation of sodium $\left(\mathrm{Na}^{+}\right)$ and chloride $\left(\mathrm{Cl}^{-}\right)$in plants, but also it affects the antagonism of the absorption of essential elements such as potassium $\left(\mathrm{K}^{+}\right)$, calcium $\left(\mathrm{Ca}^{++}\right)$and magnesium $\left(\mathrm{Mg}^{++}\right)$in competition with $\mathrm{Na}^{+}$and nitrates (NO) in contrast with $\mathrm{Cl}^{-}$(Zörb et al., 2005).
Several researchers have focused their work in particular on the selection of suitable varieties in similar regions, either by genetic improvement which is undoubtedly the most accessible means or by an in-depth study of the various adaptation mechanisms. Improving tolerance to salinity and the pathogen $P$. megakarya would be of great importance for a cash crop such as cocoa when grown in coastal regions of Cameroon whose soils pose salinity problems.

The present work aims to contribute to improving the tolerance of the cocoa tree against the attack of $P$. megakarya and against salt stress in coastal regions through the selection of hybrid genotypes tolerant to this pathogen and to salt stress.

\section{Materials and methods}

\section{Plant material}

The plant material used was made up of two $T$. cacao clones: a Trinitario from Trinidad and Tobago (SNK13) and an Amazonian high from the Tafo collection from Ghana (T79 / 501) to produce a hybrid family. The offspring were obtained by manual pollination in the field genomic bank of the Agricultural Research Institute for Development (IRAD) in Barombi-kang. The experimental material used consisted of twenty-four hybrid genotypes of the cocoa tree F79SB progeny.

\section{Fungal material}

The fungal material consisted of a local strain of $P$. megakarya from the cocoa farm of the upper chiefdom of Ndogbong.

\section{Methods}

\section{Sowing and monitoring of bean germination in the nursery}

Plastic pots, $30 \mathrm{~cm}$ high and $12 \mathrm{~cm}$ wide were filled with humified earth obtained from a mixture of dead leaf powder and undergrowth from the Faculty of Sciences of the University of Douala. Before sowing the beans, the pots were well watered very early in the morning. The beans were sown flat to a depth of $1 \mathrm{~cm}$. The nursery was watered daily for 15 days to trigger the germination of the beans. After this period, watering was done 
once every two days. Regular manual weeding of the pots was carried out in order to eliminate weeds and avoid water and nutritional competition.

Evaluation of the impact of Phytophthora megakarya infection on cocoa leaf discs in the absence and presence of sodium chloride ( $\mathrm{NaCl}$ ) and sodium chloride associated with calcium chloride $\left(\mathrm{CaCl}_{2}\right)$ at different concentrations

The methods used to assess the sensitivity of these hybrid genotypes are the same before and after the treatments with $\mathrm{NaCl}$ and with $\mathrm{NaCl}$ associated with $\mathrm{CaCl}_{2}$.

\section{Isolation and purification of the Phytophthora megakarya strain from pods}

From an infected pod, the whitish down corresponding to the spores was scraped off and placed on a small pea-agar (SPA) culture medium containing per liter of solution $65 \mathrm{~g}$ of peas, $15 \mathrm{~g}$ of agar previously sterilized at autoclaving for 30 minutes at $120{ }^{\circ} \mathrm{C}$. After sterilization, the medium is poured hot into the Petri dishes under the hood with horizontal laminar flow and previously disinfected. For the transplanting of $P$. megakarya, after cooling and solidification of the culture medium at room temperature, the whitish duvets were placed in the center of the dish containing the fresh culture medium at the rate of one disc per Petri dish.

On this medium, the thallus developed in the absence of bacteria. After the thallus has formed, a mycelial fragment is taken from the growth front of the culture and transferred to petri dishes on agar medium based on peas. Incubation was carried out at $26{ }^{\circ} \mathrm{C}$ in the dark for 6 to 7 days. The virulence of the strain was preserved through weekly subculturing on agar pea medium.

\section{Zoospore production}

Ten days before the planned date of infection, the strain to be used for infection is subcultured on a SPA medium in a Petri dish $(10 \mathrm{~cm})$. The Petri dishes were placed for three days at $25{ }^{\circ} \mathrm{C}$ in the dark. Then they were placed at $25{ }^{\circ} \mathrm{C}$ in the light (photoperiod $12 \mathrm{~h} / \mathrm{12h}$ ) in order to obtain the formation of the sporocysts at the origin of the production of zoospores.

On the day of infection, 4 to $5 \mathrm{~mL}$ of sterile distilled water was added to each Petri dish. The Petri dishes will then be placed in a refrigerator at $4{ }^{\circ} \mathrm{C}$ for 30 minutes. The cold shock promotes the release of the zoospores contained in the sporocysts. The Petri dishes were then placed at 20 ${ }^{\circ} \mathrm{C}$ for two hours so that the zoospores could be released into the water. Then the solution containing the zoospores will be collected in a beaker. A zoospore count was then made using a Malassez cell. Infection with the calibrated suspension was done as quickly as possible to prevent zoospores from losing their ability to swim in water.

\section{Artificial infection on leaf discs in the laboratory}

Leaves approximately two months of age (50 to 60 days) of non-woody twigs as described by Nyassé et al. (1995) were collected very early in the morning on each hybrid genotype. The $15 \mathrm{~cm}$ diameter discs are cut from these sheets and placed upside down in plastic dishes on toilet paper soaked in water. The covered dishes were incubated overnight at approximately $25{ }^{\circ} \mathrm{C}$. Infections were carried out the morning of the following day with $10 \mu \mathrm{L}$ of $P$. megakarya suspension calibrated at 300.000 zoospores / $\mathrm{mL}$ previously prepared as described above and deposited with a micropipette in 5 repetitions. The size of the necrotic lesion was measured on the 3, 4, 5, 6 and 7 days after infection. The diameters of the necrotic spots were measured and the area was calculated using the formula of Blaha and Lotodé (1976).

\section{Artificial infection on whole leaves in the greenhouse}

For this infection, the whole leaves attached to the seedlings of each hybrid genotype were washed and infected with $5 \mu \mathrm{L}$ of suspension of $P$. megakarya calibrated at $24 \times 10^{5}$ zoospores / mL previously prepared as described previously deposited with a repeating micropipette. The size of the necrotic lesion was measured on the $3,4,5$, 6 and 7 days after infection. 


\section{Preparation of experimental solutions and induction of stress}

\section{Preparation of experimental solutions}

Three sets of $12 \mathrm{~g}$ of $\mathrm{KNO}_{3}, 12.4 \mathrm{~g}$ of $\mathrm{MgSO}_{4}$ and $15 \mathrm{~g}$ of $\mathrm{Ca}_{2} \mathrm{NO}_{3}$ were weighed using a precision balance (KERN EMB 600-2) to prepare the nutrient solution of Wacquant (1974) and introduced into a $20 \mathrm{~L}$ plastic can containing distilled water corresponding to the solution (S1). For the preparation of the $100 \mathrm{mM}$ sodium solution corresponding to $(\mathrm{S} 2), 120 \mathrm{~g}$ of $\mathrm{NaCl}$ were weighed and introduced into a $20 \mathrm{~L}$ plastic container containing distilled water. Finally the saline solution $\left(\mathrm{S}_{3}\right)$ was composed of a combination of two salts $\mathrm{NaCl}+\mathrm{CaCl}_{2}(\mathrm{v} / \mathrm{v})$ at 100,200 and $300 \mathrm{mM}$. In addition, $\mathrm{NaCl}$ associated with $\mathrm{CaCl}_{2}$ produces a saline medium. As for the control solution (So), it consists only of distilled water. Four types of experimental solutions were obtained at the end: (i) the control solution (So) being only distilled water; (ii) the Wacquant nutrient solution (S1); (iii) the sodium solution (S2) consisting of $100 \mathrm{mM} \mathrm{NaCl}$ (120 g); (iv) saline solution $\left(\mathrm{NaCl}+\mathrm{CaCl}_{2}\right)$ at concentrations 100, 200 and $300 \mathrm{mM}$.

\section{Induction of stress}

The experimental solutions ( $\mathrm{S} 1, \mathrm{~S} 2, \mathrm{~S} 3)$ obtained having been used for watering the plants and for each treatment to induce stress (sodium and saline) in the plants were spread over a period of two weeks for each concentration. Then each treatment was interspersed with a spray of Wacquant nutrient solution (S1) also over a period of two weeks. Two hundred $\mathrm{ml}$ of solution were used to induce the various stresses as follows: 100 $\mathrm{mL}$ for early watering and the remaining $100 \mathrm{~mL}$ for evening watering (also valid for Wacquant's nutrient solution) (Wacquant, 1974).

\section{Statistical analyzes}

Statistical analyzes were performed with SPSS Version 16.0 software. Analysis of variances (ANOVA) and averages were done in order to observe the differences between the treatments, the Duncan Test was done to compare the different treatments and the hierarchical classification to group the hybrid genotypes according to their level tolerance to $P$. megakarya on the effect of salinity at the $5 \%$ threshold.

\section{Results}

Evaluation of the development of necrosis on leaf disks and whole leaves in the absence and in the presence of $\mathrm{NaCl}$

\section{Germination rate}

After sowing the beans in the plastic pots followed by watering as described in the methodology, we observed the germination of the first beans at the end of the first week. This germination continued until the end of the second week. Following observations of the germination of beans from this hybrid family, we recorded a germination rate of 92.30\% (Table 1).

\section{Artificial infection test on leaf discs and attached leaves}

The necrotic surfaces were measured on leaf discs in the genotypes of the F79SB progeny as well as in the parental genotypes from day 3 to day 7 after the artificial infection in the absence of $\mathrm{NaCl}$. Analysis of variance indicated that there was a significant difference $(\mathrm{P}<0.05)$ depending on the day and the genotype in the development of necrosis. Day 3 after infection is marked by the appearance of necrosis in the parental genotypes and in $15 \%$ of hybrid genotypes (F79SB6, F79SB14, F79SB16, F79SB17, F79SB19 and F79SB24). On this date, there is no significant difference in the parental genotypes and the hybrid genotypes except the genotype F79SB14 which showed the greatest necrotic surface (0.044 \pm 0.02) as well as a significant difference compared to the two parental genotypes and the other hybrid genotypes. The F79SB24 genotype is the one that showed the smallest area of necrosis $(0.003 \pm 0)$ on this date. On day 4 after infection, $95.83 \%$ of the hybrid genotypes showed a development of necrosis except the genotype F79SB13 which is marked by an absence of necrosis. From day 5; necrosis is observed in all hybrid genotypes up to day 7 and a significant difference $(\mathrm{P}<0.05)$ has been observed between the two parents and their hybrid genotypes over time. On day 7; the parental genotype SNK413 showed the lowest necrotic surface $(1.070 \pm$ 
0.103) compared to the parent T79 / 501 (1.766 \pm o). He is therefore considered the best parent. In addition, $62.50 \%$ of the hybrid genotypes showed a surface of necrosis smaller than that of the best parent (F79SB1, F79SB2, F79SB3, F79SB4, F79SB5, F79SB7, F79SB8, F79SB10, F79SB11, F79SB12, F79SB13, F79SB1818 and F79SB23) but on the other hand $33.33 \%$ of the hybrid genotypes showed an area of inferior necrosis compared to the sensitive parent (F79SB6, F79SB9, F79SB15, F79SB16, F79SB17, F79SB19, F79SB22 and F79SB24). Throughout the duration of the evaluation of the development of necrosis, the hybrid genotype F79SB14 is the one which showed large necrotic areas (0.044 $\pm 0.02-1.772$ \pm 0.235) (Table 2).

Table 1. Germination rate (\%) of plants.

\begin{tabular}{lll}
\hline Weeks & \% of plants germinated & \% of plants not germinated \\
\hline $\mathbf{1}^{\text {st }}$ & 57.69 & 42.31 \\
$2^{\text {nd }}$ & 92.30 & 7.70 \\
\hline
\end{tabular}

Table 2. Development of the necrotic surface $\left(\mathrm{cm}^{2}\right)$ on the leaves of the parental genotypes and hybrids of the F79SB progeny in the absence of $\mathrm{NaCl}$.

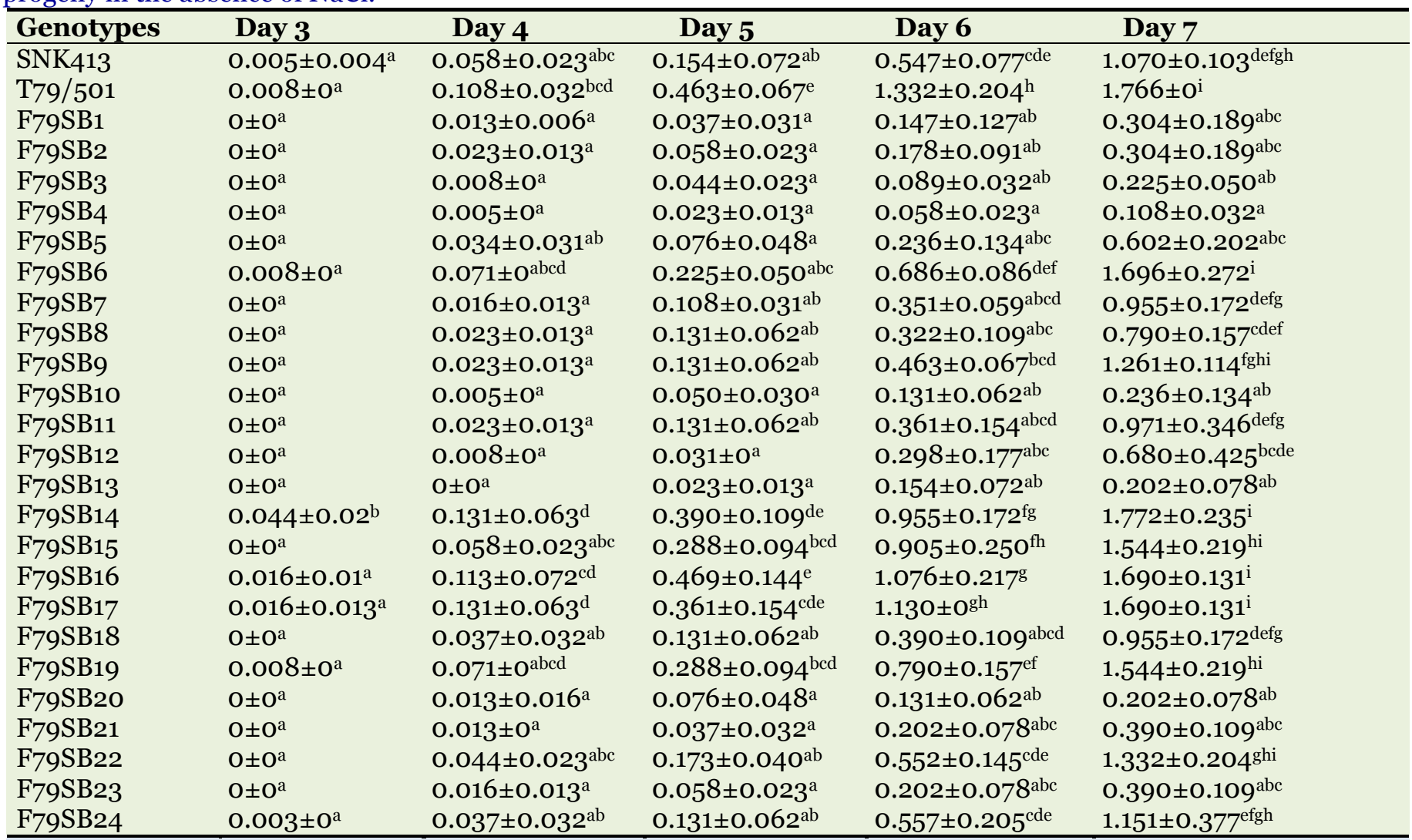

Values with the same letter on the same column are not significantly different at $\mathrm{P}<0.05$ according to Duncan's test.

Under sodium treatment $(\mathrm{NaCl}$ at $100 \mathrm{mM})$, the development of necrosis was evaluated on the attached leaves of cocoa tree in the nursery. Table 3 presents the development of the necrotic surface $\left(\mathrm{cm}^{2}\right)$ on attached leaves of cocoa tree of the hybrid genotypes of the F79SB progeny under sodium treatment $(\mathrm{NaCl}$ at $100 \mathrm{mM})$. Analysis of variance indicated that there was a significant difference $(\mathrm{P}$ $<0.05$ ) depending on the day and the genotype in the development of necrosis. On day 3 after infection, necrosis was observed in all hybrid genotypes. There is no significant difference 
( $\mathrm{P}<0.05)$ between hybrid genotypes with large necrotic areas. On this date, the F79SB3 genotype was the one that presented the smallest necrotic surface (0.116 \pm 0.053$)$. From day 4 , an increasing evolution of the development of necrosis was observed up to day 7 in different hybrid genotypes subjected to sodium treatment. At this date, $54.17 \%$ of the hybrid genotypes showed necrotic surfaces lower than $3.5 \mathrm{~cm}^{2}$ which means that they are tolerant to $P$. megakarya under sodium stress.
In contrast, the hybrid genotypes F79SB1 (6.015 \pm 0.289), F79SB2 (6.296 \pm 0.328$),$ F79SB6 (6.296 \pm 0.328), F79SB9 (6.518 \pm 0.225), F79SB11 (6.518 \pm 0.225), F79SB16 (6.579 \pm 0.272), F79S \pm 0.295), F79SB21 (6.343 \pm 0.018), F79SB22 (6.243 \pm 0.283), F79SB23 (6.459 \pm 0.299) and F79SB24 $(6.639 \pm 0.219)$ showed necrotic surfaces greater than $6 \mathrm{~cm}^{2}$ thus showing their great sensitivity to the pathogen under stress sodium (Table 3) hence their elimination from the selection process.

Table 3. Development of the necrotic surface $\left(\mathrm{cm}^{2}\right)$ on the leaves of hybrids of the F79SB progeny under sodium treatment $(\mathrm{NaCl}$ at $100 \mathrm{mM})$.

\begin{tabular}{|c|c|c|c|c|c|}
\hline Genotypes & Day 3 & Day 4 & Day 5 & Day 6 & Day 7 \\
\hline F79SB1 & $0.307 \pm 0.065^{\text {cd }}$ & $1.278 \pm 0.129^{g}$ & $2.614 \pm 0.187^{f}$ & $4.802 \pm 0.255^{f}$ & $6.015 \pm 0.289^{f}$ \\
\hline F79SB2 & $0.373 \pm 0.079^{\text {de }}$ & $1.408 \pm 0.157^{\mathrm{gh}}$ & $2.799 \pm 0.221^{\mathrm{fg}}$ & $5.052 \pm 0.296^{\mathrm{fgh}}$ & $6.296 \pm 0.328^{\mathrm{fgh}}$ \\
\hline F79SB3 & $0.116 \pm 0.053^{\mathrm{a}}$ & $0.347 \pm 0.093^{\mathrm{a}}$ & $0.905 \pm 0.146^{\mathrm{a}}$ & $1.611 \pm 0.193^{\mathrm{a}}$ & $2.234 \pm 0.228^{\mathrm{a}}$ \\
\hline F79SB4 & $0.298 \pm 0.045^{\mathrm{cd}}$ & $0.636 \pm 0.065^{\text {cde }}$ & $1.350 \pm 0.095^{\mathrm{cd}}$ & $2.200 \pm 0.122^{\mathrm{cd}}$ & $2.926 \pm 0.142^{\mathrm{cd}}$ \\
\hline F79SB5 & $0.151 \pm 0.017^{\mathrm{ab}}$ & $0.414 \pm 0.025^{\mathrm{ab}}$ & $1.011 \pm 0.050^{\mathrm{a}}$ & $1.751 \pm 0.077^{\mathrm{ab}}$ & $2.396 \pm 0.099^{\mathrm{a}}$ \\
\hline F79SB6 & $0.373 \pm 0.079^{\mathrm{de}}$ & $1.408 \pm 0.157^{\mathrm{gh}}$ & $2.799 \pm 0.221^{\mathrm{fg}}$ & $5.052 \pm 0.296^{\mathrm{fgh}}$ & $6.296 \pm 0.328^{\mathrm{fgh}}$ \\
\hline F79SB7 & $0.477 \pm 0.134^{\mathrm{e}}$ & $0.889 \pm 0.185^{f}$ & $1.698 \pm 0.25 \mathrm{O}^{\mathrm{e}}$ & $2.628 \pm 0.305^{\mathrm{e}}$ & $3.411 \pm 0.344^{\mathrm{e}}$ \\
\hline F79SB8 & $0.193 \pm 0.052^{\mathrm{ab}}$ & $0.479 \pm 0.087^{a b c}$ & $1.107 \pm 0.13^{\mathrm{ab}}$ & $1.874 \pm 0.169^{\mathrm{ab}}$ & $2.540 \pm 0.196^{\mathrm{ab}}$ \\
\hline F79SB9 & $0.426 \pm 0.058^{e}$ & $1.512 \pm 0.105^{\mathrm{h}}$ & $2.946 \pm 0.148^{g}$ & $5.250 \pm 0.199^{\mathrm{gh}}$ & $6.518 \pm 0.225^{\mathrm{gh}}$ \\
\hline F79SB10 & $0.395 \pm 0.078^{\mathrm{de}}$ & $0.783 \pm 0.118^{\mathrm{ef}}$ & $1.545 \pm 0.157^{\mathrm{de}}$ & $2.428 \pm 0.187^{\mathrm{de}}$ & $3.175 \pm 0.207^{\mathrm{de}}$ \\
\hline F79SB11 & $0.426 \pm 0.058^{e}$ & $1.512 \pm 0.105^{\mathrm{h}}$ & $2.946 \pm 0.148^{g}$ & $5.250 \pm 0.199^{\mathrm{gh}}$ & $6.518 \pm 0.225^{\mathrm{gh}}$ \\
\hline F79SB12 & $0.399 \pm 0.104^{\mathrm{de}}$ & $0.779 \pm 0.145^{\mathrm{ef}}$ & $1.556 \pm 0.191^{\mathrm{de}}$ & $2.463 \pm 0.228^{\mathrm{de}}$ & $3.230 \pm 0.255^{\mathrm{de}}$ \\
\hline F79SB13 & $0.402 \pm 0.081^{\mathrm{de}}$ & $0.783 \pm 0.113^{\text {ef }}$ & $1.561 \pm 0.16 \mathrm{O}^{\mathrm{de}}$ & $2.467 \pm 0.203^{\mathrm{de}}$ & $3.234 \pm 0.234^{\mathrm{de}}$ \\
\hline F79SB14 & $0.254 \pm 0.030^{b c}$ & $0.579 \pm 0.048^{\mathrm{bcd}}$ & $1.254 \pm 0.065^{\mathrm{bc}}$ & $2.061 \pm 0.078^{\mathrm{bc}}$ & $2.754 \pm 0.089^{\mathrm{bc}}$ \\
\hline F79SB15 & $0.462 \pm 0.027^{\mathrm{e}}$ & $0.873 \pm 0.033^{\mathrm{f}}$ & $1.674 \pm 0.050^{\mathrm{e}}$ & $2.595 \pm 0.069^{\mathrm{e}}$ & $3.370 \pm 0.084^{e}$ \\
\hline F79SB16 & $0.442 \pm 0.070^{\mathrm{e}}$ & $1.539 \pm 0.127^{\mathrm{h}}$ & $2.985^{ \pm 0.179^{g}}$ & $5.303 \pm 0.240^{\mathrm{gh}}$ & $6.579 \pm 0.272^{\mathrm{gh}}$ \\
\hline F79SB17 & $0.367 \pm 0.119^{\mathrm{de}}$ & $0.736 \pm 0.172^{\text {def }}$ & $1.482 \pm 0.242^{\text {cde }}$ & $2.355 \pm 0.302^{\text {cde }}$ & $3.097 \pm 0.345^{\text {cde }}$ \\
\hline F79SB18 & $0.395 \pm 0.030^{\text {de }}$ & $0.783 \pm 0.045^{\text {ef }}$ & $1.545 \pm 0.060^{\mathrm{de}}$ & $2.428 \pm 0.073^{\mathrm{de}}$ & $3.175^{ \pm 0.081^{\mathrm{de}}}$ \\
\hline F79SB19 & $0.414 \pm 0.074^{\mathrm{de}}$ & $1.486 \pm 0.139^{\mathrm{h}}$ & $2.911 \pm 0.195^{\mathrm{g}}$ & $5.203 \pm 0.263^{\mathrm{gh}}$ & $6.467 \pm 0.295^{\mathrm{gh}}$ \\
\hline F79SB20 & $0.399 \pm 0.053^{\mathrm{de}}$ & $0.791 \pm 0.075^{\mathrm{ef}}$ & $1.55^{2} \pm 0.105^{\mathrm{de}}$ & $2.434 \pm 0.131^{\mathrm{de}}$ & $3.179 \pm 0.150^{\mathrm{de}}$ \\
\hline F79SB21 & $0.381 \pm 0.005^{\mathrm{de}}$ & $1.429 \pm 0.000^{g h}$ & $2.830 \pm 0.005^{\mathrm{fg}}$ & $5.095 \pm 0.009^{\mathrm{fgh}}$ & $6.343 \pm 0.018^{\mathrm{fgh}}$ \\
\hline F79SB22 & $0.360 \pm 0.068^{\text {cde }}$ & $1.380 \pm 0.135^{\mathrm{gh}}$ & $2.761 \pm 0.190^{f g}$ & $5.003 \pm 0.255^{\mathrm{fg}}$ & $6.243 \pm 0.283^{\mathrm{fg}}$ \\
\hline F79SB23 & $0.412 \pm 0.075^{\mathrm{de}}$ & $1.486 \pm 0.139^{\mathrm{h}}$ & $2.909 \pm 0.197^{g}$ & $5.199 \pm 0.265^{\mathrm{gh}}$ & $6.459 \pm 0.299^{\mathrm{gh}}$ \\
\hline F79SB24 & $0.457 \pm 0.056^{\mathrm{e}}$ & $1.567 \pm 0.105^{\mathrm{h}}$ & $3.024 \pm 0.147^{\mathrm{g}}$ & $5.35^{6} \pm 0.196^{\mathrm{h}}$ & $6.639 \pm 0.219^{\mathrm{h}}$ \\
\hline
\end{tabular}

Values with the same letter on the same column are not significantly different at $\mathrm{P}<0.05$ according to Duncan's test.

\section{Hierarchical classification of genotypes in the absence and presence of $\mathrm{NaCl}$}

The development of the necrotic surface as a function of the days made it possible to classify hierarchically the parental genotypes and the hybrid genotypes of the F79SB progeny. This hierarchical classification was obtained on the basis of the necrosis area of the leaves from day 3 to day 7 in the absence of $\mathrm{NaCl}$.

The parental genotypes and the hybrid genotypes were produced at $95 \%$ homogeneity (Fig. 1). This hierarchical classification made it possible to distinguish 9 groups of individuals. Groups 3 and 8 , consisting respectively of 2 and 5 genotypes each from which the parental genotype $\mathrm{T}_{79} / 501$ is based, are characterized by large necrotic areas and are considered as very sensitive genotypes. Groups 1 and 4, consisting respectively of 3 and 2 genotypes, each having the parental genotype SNK413, presented medium necrotic surfaces and are considered to be sensitive. Groups 5 and 6 also made up respectively of 3 and 2 genotypes each are 
characterized by small necrotic surfaces and therefore considered to be tolerant. Groups 2, 7 and 9 made up respectively of 3, 4 and 2 genotypes each presented very small necrotic surfaces and are therefore considered as very tolerant genotypes (Fig. 1).

Otherwise, Fig. 2 presents the hierarchical classification of the hybrid genotypes of the F79SB progeny also obtained on the basis of the necrosis surface of the attached leaves of cocoa trees in the greenhouse from day 3 to day 7 under sodium treatment $(\mathrm{NaCl}$ at $100 \mathrm{mM})$. This classification made it possible to distinguish 5 groups of individuals. Groups 1 and 2 consisting respectively of 6 and 2 genotypes each are characterized by necrotic surfaces less than 3.5 $\mathrm{cm}^{2}$ therefore considered to be tolerant. Groups 3, 4 and 5 made up respectively of 2, 2 and 1 genotypes each presented necrotic surfaces smaller than that of groups 1 and 2 and are in this case considered as hybrid genotypes very tolerant to the pathogen under sodium constraint $(\mathrm{NaCl}$ at 100mM) (Fig. 2).

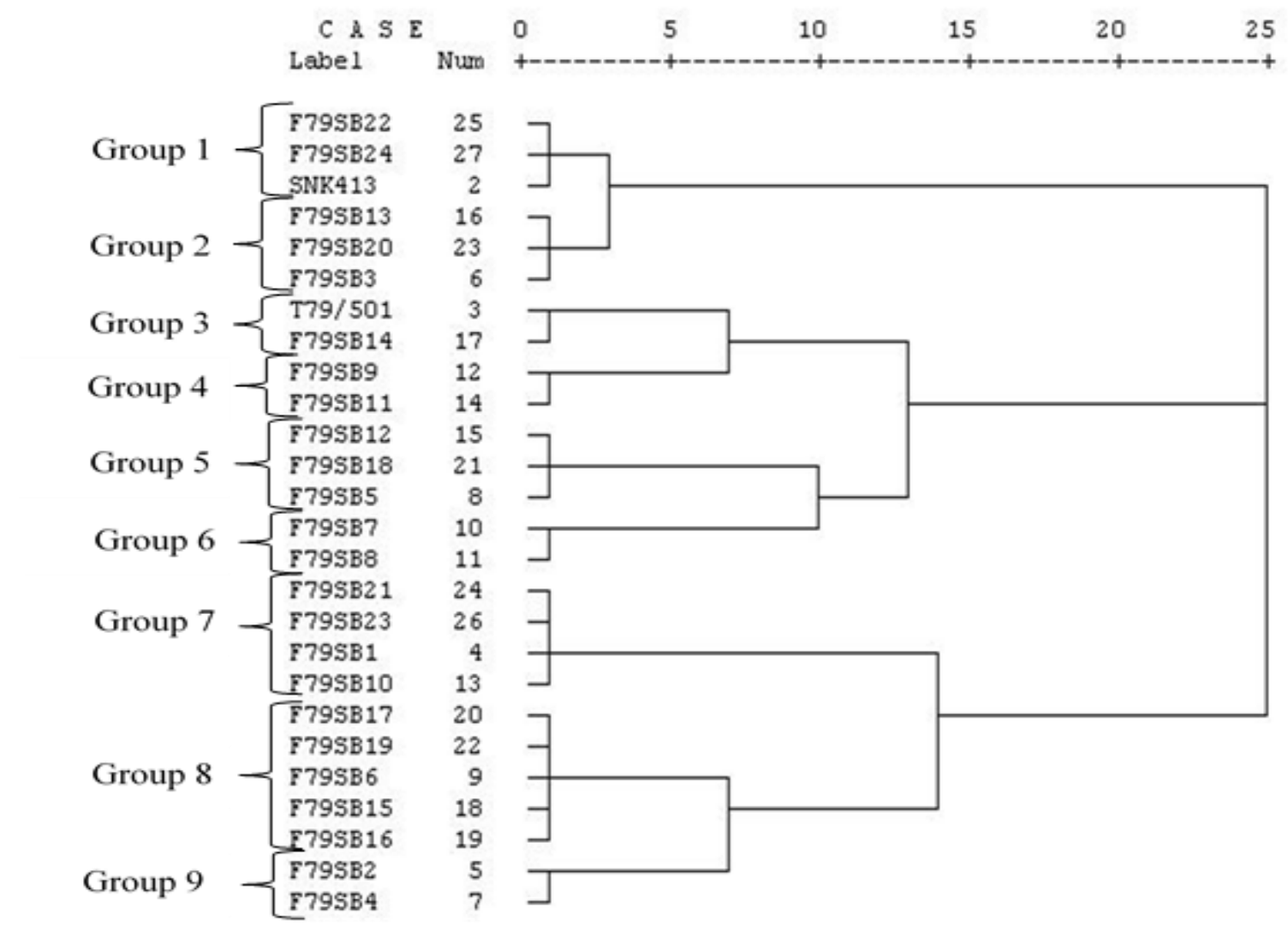

Fig. 1: Hierarchical classification of hybrids of the F79SB progeny obtained on the basis of the necrotic surface of the leaves from day 3 to day 7 in the absence of $\mathrm{NaCl}$.

Evaluation of the development of necrosis in the presence of $\mathrm{NaCl}$ associated with calcium chloride $\left(\mathrm{CaCl}_{2}\right)$ at different concentrations on whole leaves in the greenhouse

The methods used to assess the development of necrosis in hybrid genotypes subjected to the $\mathrm{NaCl}$ $+\mathrm{CaCl}_{2}$ treatment are the same as those used before and after the $\mathrm{NaCl}$ treatment.

\section{Artificial infection test on attached leaves}

Under saline treatment, the evaluation of the development of necrosis was done on attached leaves of cocoa tree in the nursery. Analysis of variance showed that there was a significant difference $(\mathrm{P}<0.05)$ depending on the day and the genotype in the development of necrosis. Under saline treatment at $100 \mathrm{mM}(\mathrm{NaCl}+$ $\mathrm{CaCl}_{2}$ ), day 3 after infection was marked by the 
appearance of necrosis in all the hybrid genotypes of the F79SB progeny. At that date, a significant difference was observed in the hybrid genotypes. The hybrid genotype F79SB3 was the one that developed the smallest necrotic surface (0.161 \pm 0.058) while F79SB20 developed the largest necrotic surface at this date $(0.534 \pm 0.063)$. On day 4 after infection, all genotypes had a necrotic surface less than $1 \mathrm{~cm}^{2}$. On day $5,76.92 \%$ of the genotypes presented a necrotic surface greater than $1 \mathrm{~cm}^{2}$ and a progressive evolution of the necrosis was observed until day 7 . On this date (day7), there was no difference significant ( $P$ $<0.05$ ) between the hybrid genotypes with a large necrotic surface (F79SB7, F79SB10, F79SB15, F79SB18 and F79SB20) and the F79SB3 genotype remained the one which showed the smallest necrotic surface (Table 4).

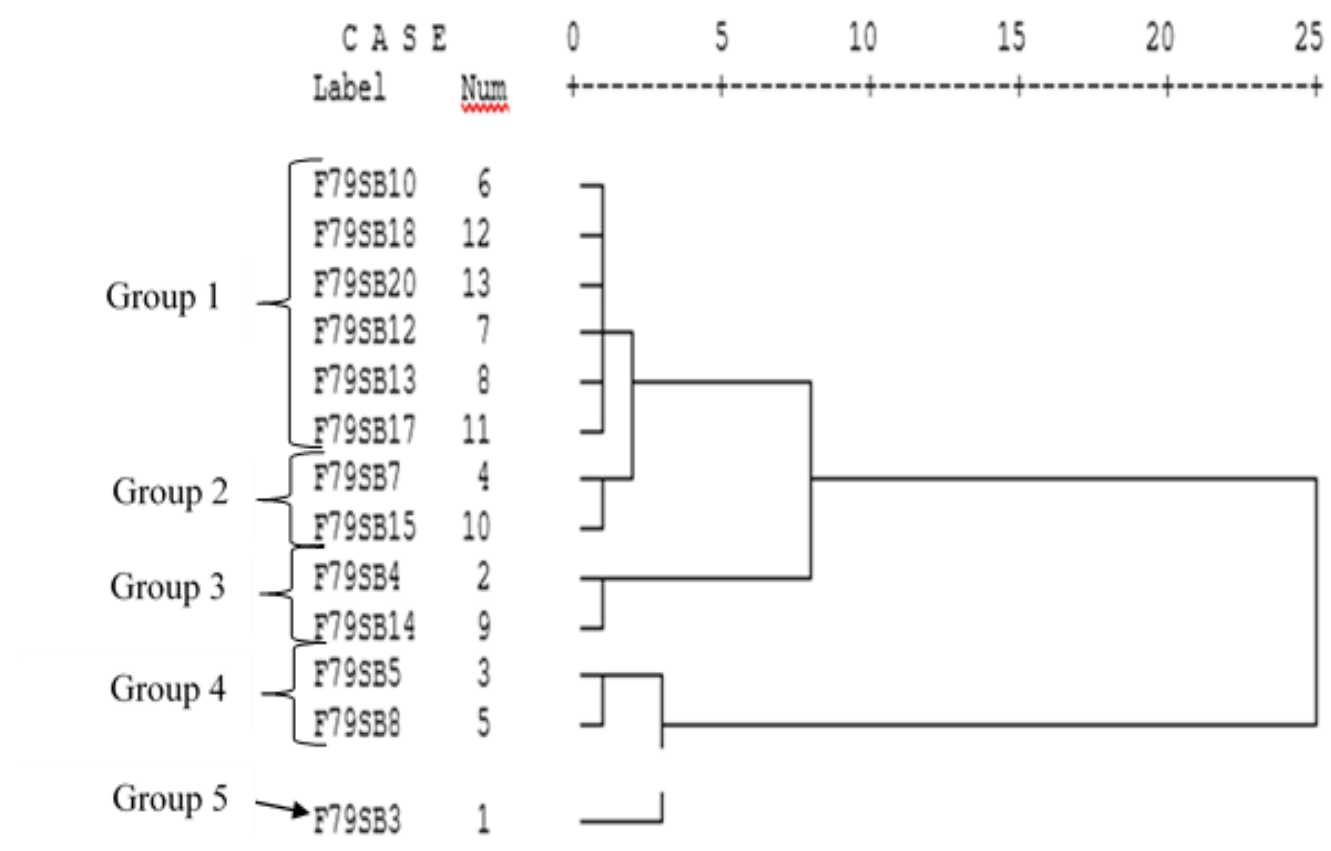

Fig. 2: Hierarchical classification of hybrids of the F79SB progeny obtained on the basis of the necrotic surface of the leaves from day 3 to day 7 in the presence of $\mathrm{NaCl}$.

Table 4. Development of the necrotic surface $\left(\mathrm{cm}^{2}\right)$ on the leaves of hybrids of the F79SB progeny under saline treatment $\left(\mathrm{NaCl}+\mathrm{CaCl}_{2}\right.$ at $\left.100 \mathrm{mM}\right)$.

\begin{tabular}{|c|c|c|c|c|c|}
\hline Genotypes & Day 3 & Day 4 & Day 5 & Day 6 & Day 7 \\
\hline F79SB3 & $0.161 \pm 0.05^{a}$ & $0.287 \pm 0.077^{a}$ & $0.789 \pm 0.128^{a}$ & $0.789 \pm 0,128^{a}$ & $2.547 \pm 0.231^{\mathrm{a}}$ \\
\hline F79SB4 & $0.307 \pm 0.047^{\mathrm{abc}}$ & $0.473 \pm 0.059^{\mathrm{abc}}$ & $1.085 \pm 0.090^{b c}$ & $1.085 \pm 0,090^{b c}$ & $3.064 \pm 0.153^{\mathrm{bcd}}$ \\
\hline F79SB5 & $0.216 \pm 0.040^{\mathrm{ab}}$ & $0.360 \pm 0.051^{\mathrm{ab}}$ & $0.909 \pm 0.082^{a b}$ & $0.909 \pm 0,082^{a b}$ & $2.761 \pm 0.146^{\mathrm{ab}}$ \\
\hline F79SB7 & $0.511 \pm 0.162^{\mathrm{de}}$ & $0.718 \pm 0.193^{\mathrm{de}}$ & $1.441 \pm 0.274^{\mathrm{de}}$ & $1.441 \pm 0,274^{\mathrm{de}}$ & $3.639 \pm 0.436^{\mathrm{ef}}$ \\
\hline F79SB8 & $0.263 \pm 0.084^{\mathrm{abc}}$ & $0.418 \pm 0.106^{\mathrm{abc}}$ & $0.999 \pm 0.166^{\mathrm{abc}}$ & $0.999 \pm 0,166^{\mathrm{abc}}$ & $2.914 \pm 0.286^{\mathrm{abc}}$ \\
\hline F79SB10 & $0.511 \pm 0.162^{\mathrm{de}}$ & $0.718 \pm 0.193^{\mathrm{de}}$ & $1.441 \pm 0.274^{\mathrm{de}}$ & $1.441 \pm 0,274^{\mathrm{de}}$ & $3.639 \pm 0.436^{\mathrm{ef}}$ \\
\hline F79SB12 & $0.393 \pm 0.142^{\text {cde }}$ & $0.577 \pm 0.172^{\text {cde }}$ & $1.237 \pm 0.254^{\text {cde }}$ & $1.237 \pm 0,254^{\text {cde }}$ & $3 \cdot 309 \pm 0.415^{\text {cdef }}$ \\
\hline F79SB13 & $0.385 \pm 0.064^{\text {cde }}$ & $0.569 \pm 0.077^{\text {cde }}$ & $1.229 \pm 0.114^{\text {cde }}$ & $1.229 \pm 0,114^{\text {cde }}$ & $3 \cdot 301 \pm 0.186^{\text {cdef }}$ \\
\hline F79SB14 & $0.362 \pm 0.098^{\text {bcd }}$ & $0.540 \pm 0.121^{b c d}$ & $1.184 \pm 0.181^{b c d}$ & $1.184 \pm 0,181^{b c d}$ & $3.225 \pm 0.301^{\text {cde }}$ \\
\hline F79SB15 & $0.534 \pm 0.063^{\mathrm{e}}$ & $0.748 \pm 0.075^{\mathrm{e}}$ & $1.486 \pm 0.106^{\mathrm{e}}$ & $1.486 \pm 0,106^{\mathrm{e}}$ & $3.715 \pm 0.169^{e}$ \\
\hline F79SB17 & $0.420 \pm 0.136^{\text {cde }}$ & $0.611 \pm 0.166^{\text {cde }}$ & $1.286 \pm 0.245^{\text {cde }}$ & $1.286 \pm 0,245^{\mathrm{cde}}$ & $3.389 \pm 0.403^{\mathrm{def}}$ \\
\hline F79SB18 & $0.503 \pm 0.072^{\mathrm{de}}$ & $0.711 \pm 0.086^{\mathrm{de}}$ & $1.433 \pm 0.122^{\mathrm{de}}$ & $1.433 \pm 0,122^{\mathrm{de}}$ & $3.631 \pm 0.195^{\mathrm{ef}}$ \\
\hline F79SB20 & $0.534 \pm 0.063^{\mathrm{e}}$ & $0.748 \pm 0.075^{\mathrm{e}}$ & $1.486 \pm 0.106^{\mathrm{e}}$ & $1.486 \pm 0,106^{\mathrm{e}}$ & $3.715 \pm 0.169^{e}$ \\
\hline
\end{tabular}

Values with the same letter on the same column are not significantly different at P <0.05 according to Duncan's test. 
Table 5 shows the development of necrosis $\left(\mathrm{cm}^{2}\right)$ on the attached cocoa tree leaves in the nursery under saline treatment with $200 m \mathrm{M} \mathrm{NaCl}+\mathrm{CaCl}_{2}$ on the hybrid genotypes F79SB. Analysis of variance (ANOVA) indicated that there was a significant difference $(\mathrm{P}<0.05)$ depending on the day and the genotype in the development of necrosis. Due to the harmful effects of salt stress on certain genotypes, the genotypes $\mathrm{F}_{79 \mathrm{SB} 7}$ F79SB10 F79SB12 F79SB13 F79SB14 and F79SB17 were eliminated in the rest of the work. Day 3 after infection was marked by the presence of necrosis in all hybrid genotypes. On this date, a significant difference was observed in the hybrid genotypes of the F79SB progeny. The genotypes F79SB5, F79SB8 and F79SB15 developed areas of necrosis less than $1 \mathrm{~cm}^{2}$ of which F79SB15 was the one which developed the smallest necrotic area (0.605 \pm 0.143) and the largest was observed in the genotype F79SB20 (1.083 \pm 0.089$)$ on day 3.

On day 4, all the hybrid genotypes had a surface of necrosis greater than $1 \mathrm{~cm}^{2}$ and on day 5, a progressive evolution was observed until day 7 . To this date (day 7); no significant differences were observed between the hybrid genotypes which presented small areas of necrosis between them and also between the hybrid genotypes which showed a large area of necrosis (F79SB18 and F79SB20). A large difference between day 3 and day 7 necrosis was observed in certain genotypes such as F79SB5 (0.930 $\pm 0.126-2.942 \pm 0.187)$ and in the genotype with a large area of necrosis F79SB20 (1.083 $\pm 0.089-4.106 \pm 0.226)$ (Table 5).

Table 5. Development of the necrotic surface $\left(\mathrm{cm}^{2}\right)$ on the leaves of hybrids of the F79SB progeny under saline treatment $\left(\mathrm{NaCl}+\mathrm{CaCl}_{2}\right.$ at $\left.200 \mathrm{mM}\right)$.

\begin{tabular}{llllll}
\hline Genotypes & Day 3 & Day 4 & Day 5 & Day 6 & Day 7 \\
\hline F79SB3 & $1.150 \pm 0.139^{\text {cd }}$ & $1.374 \pm 0.100^{a b}$ & $1.590 \pm 0.189^{\mathrm{a}}$ & $2.039 \pm 0.215^{\mathrm{a}}$ & $2.969 \pm 0.213^{\mathrm{a}}$ \\
F79SB4 & $1.276 \pm 0.243^{\mathrm{d}}$ & $1.586 \pm 0.205^{\mathrm{b}}$ & $1.849 \pm 0.351^{\mathrm{ab}}$ & $2.606 \pm 0.273^{\mathrm{b}}$ & $3.209 \pm 0.208^{\mathrm{a}}$ \\
F79SB5 & $0.930 \pm 0.126^{\mathrm{bc}}$ & $1.225 \pm 0.133^{\mathrm{a}}$ & $1.562 \pm 0.227^{\mathrm{a}}$ & $2.096 \pm 0.123^{\mathrm{a}}$ & $2.942 \pm 0.187^{\mathrm{a}}$ \\
F79SB8 & $0.842 \pm 0.119^{\mathrm{b}}$ & $1.146 \pm 0.143^{\mathrm{a}}$ & $1.563 \pm 0.163^{\mathrm{a}}$ & $2.102 \pm 0.190^{\mathrm{a}}$ & $2.975 \pm 0.215^{\mathrm{a}}$ \\
F79SB15 $_{\text {a }}$ & $0.605 \pm 0.143^{\mathrm{a}}$ & $1.178 \pm 0.183^{\mathrm{a}}$ & $1.655 \pm 0.295^{\mathrm{a}}$ & $2.371 \pm 0.236^{\mathrm{ab}}$ & $3.256 \pm 0.276^{\mathrm{a}}$ \\
F79SB18 & $1.111 \pm 0.162^{\mathrm{cd}}$ & $1.541 \pm 0.230^{\mathrm{b}}$ & $2.041 \pm 0.212^{\mathrm{bc}}$ & $3.032 \pm 0.419^{\mathrm{c}}$ & $3.980 \pm 0.45^{\mathrm{b}}$ \\
F79SB20 $^{\mathrm{b}}$ & $1.083 \pm 0.089^{\text {cd }}$ & $1.512 \pm 0.134^{\mathrm{b}}$ & $2.336 \pm 0.077^{\mathrm{c}}$ & $3.217 \pm 0.093^{\mathrm{c}}$ & $4.106 \pm 0.226^{\mathrm{b}}$ \\
\hline
\end{tabular}

Values with the same letter on the same column are not significantly different at $\mathrm{P}<0.05$ according to Duncan's test.

The development of necrosis on attached leaves of cocoa trees was also evaluated in hybrid genotypes under saline treatment with $300 \mathrm{mM} \mathrm{NaCl}+\mathrm{CaCl}_{2}$. Table 6 presents the development of necrosis on the attached leaves of the hybrid genotypes of the F79SB progeny under saline stress at 300mM $\left(\mathrm{NaCl}+\mathrm{CaCl}_{2}\right)$. Analysis of variance showed a significant difference $(\mathrm{P}<0.05)$ depending on the day and the genotype in the development of necrosis. On day 3 after infection, necrosis was observed in all the hybrid genotypes subjected to saline treatment. There were no significant differences between the genotypes that developed small necrotic surfaces between them and between the genotypes showing the development of large necrotic surfaces. The genotypes F79SB5, F79SB8 and F79SB15 showed necrotic surfaces of less than $1 \mathrm{~cm}^{2}$. The smallest necrotic surface was observed in the F79SB8 genotype (0.948 \pm 0.122$)$ while the largest necrotic was observed in the F79SB20 genotype (1.139 \pm 0.243$)$. On day 4 , the genotypes in which a large necrotic area was observed did not show any significant difference as well as the genotypes in which a small necrotic area was observed. A significant difference was observed between the hybrid genotypes on day 5 after infection and the necrosis progressively increased until day 7. Day 7 indicated a significant difference between the genotypes in the development of necrosis. At this date, F79SB8 $(3,140 \pm 0.181)$ developed the smallest necrotic surface while F79SB20 (4.429 \pm 0.385$)$ developed the largest. A large difference between day 3 and day 7 necrosis was observed in all hybrid genotypes subjected to saline treatment with $300 \mathrm{mM} \mathrm{NaCl}$ associated with $\mathrm{CaCl}_{2}$ (Table 6). 
Table 6. Development of the necrotic surface $\left(\mathrm{cm}^{2}\right)$ on the leaves of hybrids of the F79SB progeny under saline treatment $\left(\mathrm{NaCl}+\mathrm{CaCl}_{2}\right.$ at $\left.300 \mathrm{mM}\right)$.

\begin{tabular}{|c|c|c|c|c|c|}
\hline Genotypes & Day 3 & Day 4 & Day 5 & Day 6 & Day 7 \\
\hline F79SB3 & $1.180 \pm 0.125^{\mathrm{ab}}$ & $1.623 \pm 0.141^{b}$ & $2.204 \pm 0.223^{b c d}$ & $3.026 \pm 0.261^{b c}$ & $3.633 \pm 0.362^{b c}$ \\
\hline F79SB4 & $1.250 \pm 0.150^{b}$ & $1.590 \pm 0.195^{\mathrm{b}}$ & $2.141 \pm 0.236^{b c}$ & $3.018 \pm 0.199^{b c}$ & $3.884 \pm 0.224^{c c}$ \\
\hline F79SB5 & $0.954 \pm 0.157^{\mathrm{a}}$ & $1.303 \pm 0.150^{\mathrm{a}}$ & $1.859 \pm 0.208^{\mathrm{ab}}$ & $2.722 \pm 0.213^{\mathrm{ab}}$ & $3.45^{8} \pm 0.135^{\mathrm{ab}}$ \\
\hline F79SB15 & $0.991 \pm 0.113^{a}$ & $1.266 \pm 0.127^{\mathrm{a}}$ & $1.731 \pm 0.219^{\mathrm{a}}$ & $2.869 \pm 0.143^{\mathrm{ab}}$ & $4.015 \pm 0.086^{d}$ \\
\hline F79SB18 & $1.125 \pm 0.137^{\mathrm{ab}}$ & $1.759 \pm 0.241^{b}$ & $2.465 \pm 0.248^{\mathrm{cd}}$ & $3.399 \pm 0.329^{c}$ & $4.416 \pm 0.181^{\mathrm{e}}$ \\
\hline
\end{tabular}

Values with the same letter on the same column are not significantly different at $\mathrm{P}<0.05$ according to Duncan's test.

\section{Hierarchical classification of genotypes under saline treatment}

The hierarchical classification at 95\% homogeneity of the hybrid genotypes of the F79SB progeny obtained on the basis of the necrosis areas of the attached leaves from day 3 to day 7 made it possible to distinguish different groups of individuals receiving saline treatment at different concentrations.

Under saline treatment $\left(\mathrm{NaCl}+\mathrm{CaCl}_{2}\right)$ at a concentration of $100 \mathrm{mM}, 5$ groups were distinguished. Groups 1 and 2 were made up of genotypes characterized by medium necrotic surfaces, therefore less sensitive, while groups 3,4 and 5 were characterized by small necrosis surfaces, therefore tolerant to the pathogen (Fig. 3).
At a concentration of $200 \mathrm{mM} \mathrm{NaCl}+\mathrm{CaCl}_{2}$, the hierarchical classification of the hybrid genotypes presented 6 groups. Groups 1 and 2 showed small necrotic surfaces therefore made up of tolerant hybrid genotypes. Groups 3, 4 and 5 made up respectively of genotypes F79SB15, F79SB4 and F79SB18 showed average areas of necrosis therefore less sensitive whereas F79SB20 constituting group 6 presented the largest necrotic area therefore sensitive to the pathogen (Fig. 4). However at a concentration of $300 \mathrm{mM}$, four groups were observed. Groups 1 and 4, consisting respectively of the F79SB18, F79SB20 and F79SB15 genotypes, are sensitive because they are characterized by large necrotic surfaces. On the other hand, groups 2 and 3 consisting respectively of two genotypes each showed medium necrotic surfaces therefore less sensitive to the pathogen (Fig. 5).

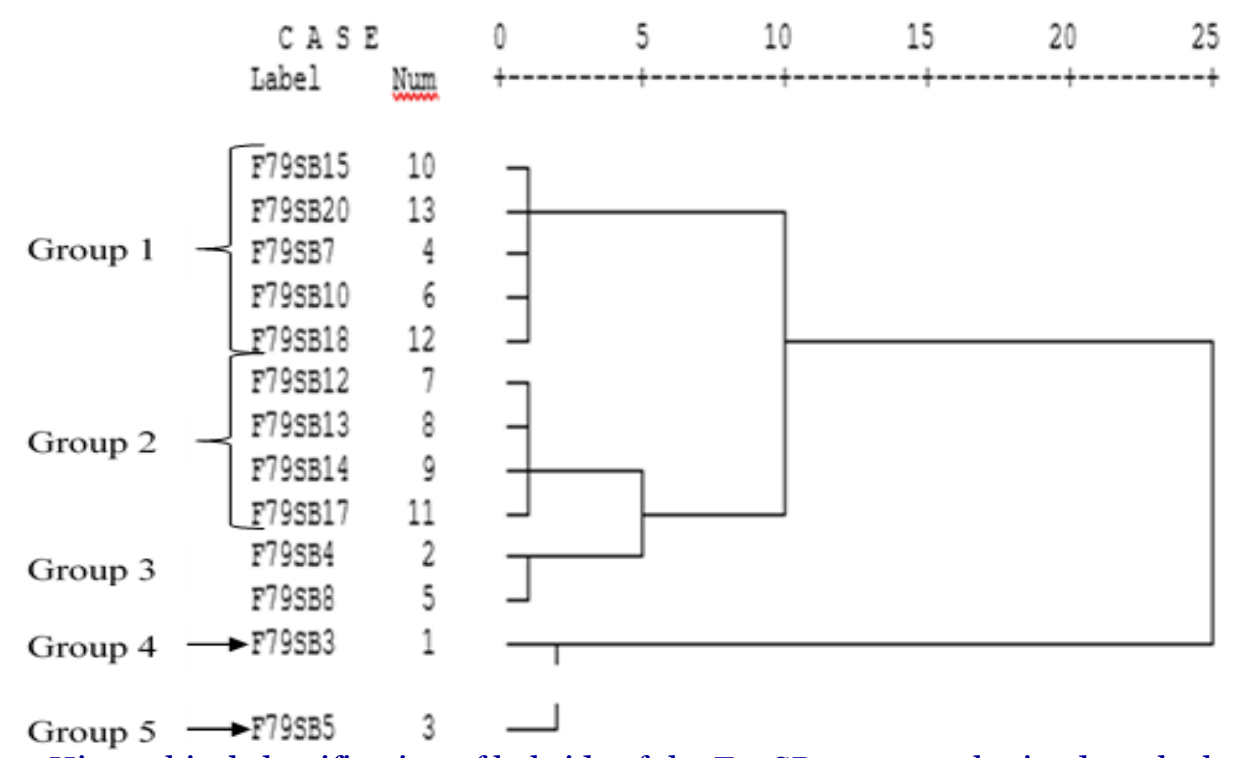

Fig. 3: Hierarchical classification of hybrids of the F79SB progeny obtained on the basis of the necrotic surface of the leaves from day 3 to day 7 in the presence of $\mathrm{NaCl}+\mathrm{CaCl}_{2}$ at $100 \mathrm{mM}$. 

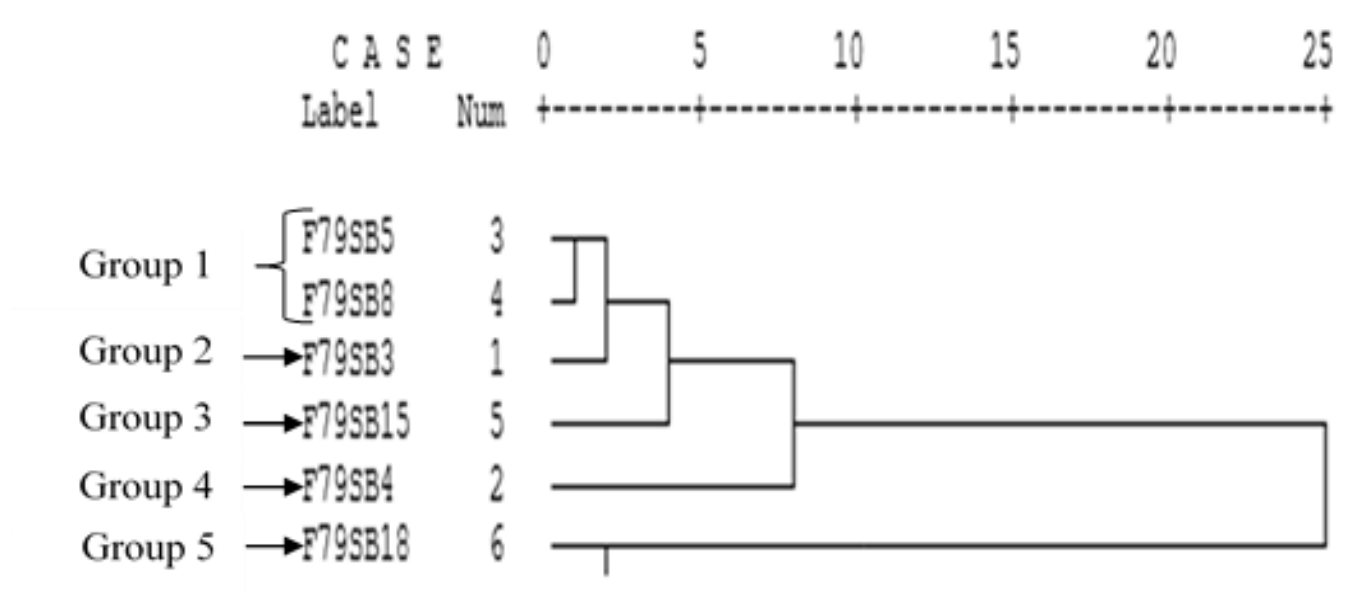

Group $6 \rightarrow$ ?95820 $7 \longrightarrow$

Fig. 4: Hierarchical classification of hybrids of the F79SB progeny obtained on the basis of the necrotic surface of the leaves from day 3 to day 7 in the presence of $\mathrm{NaCl}+\mathrm{CaCl}_{2}$ at $200 \mathrm{mM}$.
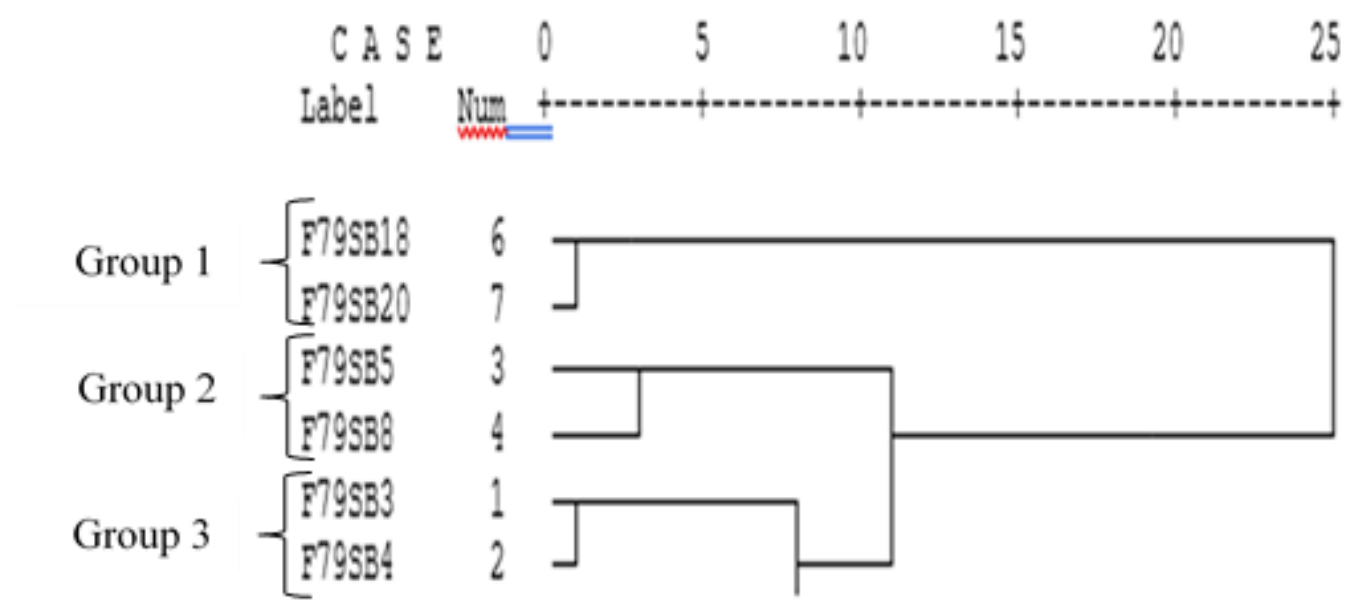

\section{Group $4 \rightarrow$ P795B15 5}

Fig. 5: Hierarchical classification of hybrids of the F79SB progeny obtained on the basis of the necrotic surface of the leaves from day 3 to day 7 in the presence of $\mathrm{NaCl}+\mathrm{CaCl}_{2}$ at $300 \mathrm{mM}$.

\section{Discussion}

Evaluation of the development of necrosis on leaf disks and whole leaves in the absence and presence of $\mathrm{NaCl}$

\section{Germination rate}

The germination rate calculated at the 1st and 2nd week after sowing showed a respective percentage of $57.69 \%$ and $92.30 \%$ proving that the germination time varies with time in this family. This variability is due to the fact that the germination time is mature-dependent and on the other hand to the fact that within the same pod, the embryos are at different stages of development. These results are similar to those obtained by Minyaka et al., 2017 on the same plant. These results confirm the words of Despréaux et al. (1989) who showed that the germination rate of cocoa beans is one of the agronomic characteristics that guide the choice of a hybrid or a clone family 
growth compared to another. On this criterion, the pollination directed between the clones T79 / 501 and SNK413 would therefore be a good growth.

\section{Artificial infection test on leaf discs and attached leaves}

The incidence and severity of $P$. megakarya in genotypes of the F79SB family were evaluated in the absence and in the presence of $\mathrm{NaCl}$. The appearance of necrosis on the infected leaf discs and leaves attached to the cocoa tree in the laboratory and in the nursery confirms the presence of $P$. megakarya. These results are in agreement with those obtained by Efombagn et al. (2011) on pods in the field, Djocgoue et al. (2010) and Ondobo et al. (2014) on the leaves attached in the nursery.

In the absence of $\mathrm{NaCl}$, the development of necrosis showed a significant effect of the date and the genotype. On day 3, there were no significant differences between the parental genotypes and the other hybrid genotypes except the genotype F79SB14 which has shown the greatest necrotic surface on day 3. But from day 4 to day 7 , there was a significant difference between the parental genotypes and the hybrid genotypes. This suggests that there is considerable genetic variability between hybrid cocoa genotypes. These results corroborate those obtained by Djocgoue et al. (2006) and Ondobo et al. (2017) on the leaves attached to the seedlings and Effa et al. (2017) on loose pods. These results also indicated that on day 7 the parental genotype SNK413 showed the lowest necrotic surface $(1.070 \pm 0.103)$ compared to the parent $\mathrm{T}_{79} / 501(1.766 \pm 0)$. He is therefore considered the best parent. In addition, $62.50 \%$ of hybrid genotypes showed a surface of necrosis smaller than that of the best parent (F79SB1, F79SB2, F79SB3, F79SB4, F79SB5, F79SB7, F79SB8, F79SB10, F79SB11, F79SB12, F79SB13, F79SB1818 and F79SB23).

On the other hand, 33.33\% of hybrid genotypes showed a lower surface of necrosis compared to the weak parent (F79SB6, F79SB9, F79SB15, F79SB16, F79SB17, F79SB19, F79SB22 and F79SB24). This differential behavior of the hybrid genotypes of this family with regard to sensitivity to $P$. megakarya accounts for the heterogeneity of the offspring for this studied trait. Similar results have been found by several authors (Nyassé et al., 2002, Efombagn et al., 2011; Nyadanu et al., 2013; Effa et al., 2017; Ondobo et al., 2017; Minyaka et al., 2017) who have shown that tolerance or sensitivity to black pod disease is a polygenic character due to heterogeneity and therefore under genetic control and can be improved genetically. In other words, the clones used as parents to generate offspring are always heterozygous for this trait, hence the appearance of tolerant and sensitive genotypes within the same family, thus confirming the best ability to combine parental genes ( Nyassé et al., 2003; Cilas et al., 2004; Pokou et al., 2008; Minyaka et al., 2018).

In the presence of $100 \mathrm{mM} \mathrm{NaCl}$, a significant difference $(\mathrm{P}<0.05)$ was observed depending on the day and the hybrid genotypes in the development of necrosis. Day 3 after infection is marked by the appearance of necrosis in all hybrid genotypes. From day 4, an increasing evolution of the development of necrosis was observed up to day 7 in the various hybrid genotypes subjected to sodium treatment. To this date, $54.17 \%$ of hybrid genotypes have shown necrotic surfaces less than $3.5 \mathrm{~cm}^{2}$, which means that they are tolerant of $P$. megakarya under sodium stress. On the other hand, some hybrid genotypes (F79SB1, F79SB2, F79SB6, F79SB9, F79SB11, F79SB16, F79SB19, F79SB2, F79SB22, F79SB23 and F79SB24) showed necrotic surfaces greater than $6 \mathrm{~cm}^{2}$, thus showing their very high sensitivity to the pathogen. Hence their elimination is the selection process. These results reveal that $\mathrm{NaCl}$ significantly increased the incidence and severity of $P$. megakarya in this hybrid family through these harmful effects on the plant. This is consistent with the work carried out by some authors (Taffouo et al., 2008; Mohameden et al., 2011; Taffouo et al., 2014; Nouck et al., 2016) who have shown that salinity affects all physiological processes in the plant as well as its development and growth.

The observation of large necrotic surfaces on the leaves of the hybrid genotypes shows that $\mathrm{NaCl}$ stimulated the rapid development of the pathogen, thus facilitating the sensitivity of the hybrid genotypes. These results corroborate those obtained by Regragui et al. (2003) who found that salinity is often believed to be responsible for the severe attack of plants by pathogenic soil fungi. 


\section{Hierarchical classification of genotypes in the absence and presence of $\mathrm{NaCl}$}

Hierarchical classification of the hybrid genotypes of the F79SB progeny also obtained on the basis of the necrosis surface of the attached leaves of the cocoa tree in the greenhouse from day 3 to day 7 under sodium treatment $(\mathrm{NaCl}$ at $100 \mathrm{mM})$ made it possible to distinguish 5 groups of hybrid genotypes. Groups 1 and 2 are considered as hybrid genotypes very tolerant to the pathogen under sodium stress $(\mathrm{NaCl}$ at $100 \mathrm{mM})$. The fact that the highly tolerant or very sensitive hybrid genotypes are in different groups confirms the genetic variability between the genotypes. These results are consistent with those obtained by Effa et al. (2017) on the same plant. In the presence of $\mathrm{NaCl}$, the sensitivity of hybrid genotypes is high with the appearance of large necrotic surfaces. These results are similar to those obtained by Boukharta et al. (2012) on the tomato.

\section{Evaluation of the development of necrosis in the presence of $\mathrm{NaCl}$ associated with calcium chloride $\left(\mathrm{CaCl}_{2}\right)$ at different concentrations on whole leaves in the greenhouse}

\section{Artificial infection test on attached leaves}

Under the different concentrations performed, the appearance of necrosis was observed in all the hybrid genotypes on day 3. A significant difference was also observed depending on the day and the genotype. Under $100 \mathrm{mM}$ of $\mathrm{NaCl}+\mathrm{CaCl}_{2}, 76.92 \%$ of the hybrid genotypes presented a necrotic surface greater than $1 \mathrm{~cm}^{2}$ on day 5 and a progressive evolution of necrosis until day 7. To date (7), there is no significant difference between hybrids with a large necrotic surface (F79SB7, F79SB10, F79SB15, F79SB18 and F79SB20). On the other hand, at $200 \mathrm{mM}$, on day 3 , areas of necrosis greater than $1 \mathrm{~cm}^{2} \quad(57.14 \%)$ were observed. These necrotic surfaces progressively evolve to reach $4.106 \pm 0.226$ for the most vulnerable genotype (F79SB20). Finally at 300 $\mathrm{mM}$, the hybrid genotypes showed necrotic surfaces greater than $1 \mathrm{~cm}^{2}$ on day 3 . On day 7 , the hybrid genotype F79SB8 developed the smallest necrotic surface while F79SB20 developed the largest. On day 7 , the necrotic surfaces change progressively as a function of the salt concentration carried out. This observation proves that the increase in salinity increases the incidence of the pathogen on the cocoa tree. These results are in agreement with those obtained by some authors such as Boukharta et al., 2012 who have shown that the attack power of the pathogen Verticillium dahliae in tomatoes increases with the concentrations of salt in the substrate. These observations are similar to those of Regragui et al. (2003) on Verticillium dahliae and Medja et al. (2009) on fusarium wilt which showed that salinity had an influence on the sensitivity of the tomato towards the pathogen.

The appearance of large necrotic surfaces could be explained by the fact that the salinity stimulates the growth of the pathogen and increases it's cellulolytic and pectinolytic capacities. Thus, colonization of tissues by the parasite was made easier by the production of these enzymes which degrade the cell walls of the host.

\section{Hierarchical classification of genotypes under saline treatment}

The hierarchical classification was made to $95 \%$ uniformity obtained on the basis of the necrosis areas of the attached leaves from day 3 to day 7 and made it possible to distinguish different groups of individuals receiving saline treatment at different concentrations. Under saline treatment $(\mathrm{NaCl}+$ $\mathrm{CaCl}_{2}$ ), 5 groups were distinguished at a concentration of $100 \mathrm{mM}, 6$ groups at $200 \mathrm{mM}$ of $\mathrm{NaCl}+\mathrm{CaCl}_{2}$ and at $300 \mathrm{mM}$, four groups were observed. In the 10omM group, we had tolerant and less sensitive individuals, the $200 \mathrm{mM}$ group consisted of tolerant, less tolerant and sensitive hybrid genotypes and finally the $300 \mathrm{mM}$ group was made up of sensitive and less sensitive hybrids. These differences in genotypic reaction to $P$. megakarya under saline stress highlight the heterogeneity of the hybrid genotypes, thus proving genetic variability within the hybrid genotypes. Similar results have been obtained by Effa et al. (2017) on the same plant.

\section{Conclusion}

As part of this work, the influence of salinity on the incidence and severity of $P$. megakarya in a hybrid family of $T$. cocoa was evaluated. It was observed that the development of necrotic surfaces was a 
function of the applied salt concentrations and the day. On day 3 after infection, at 100mM, the hybrid genotypes presented necrotic surfaces less than 1 $\mathrm{cm}^{2}$ while at 200 and $300 \mathrm{mM}$, some hybrid genotypes presented necrotic surfaces greater than $1 \mathrm{~cm}^{2}$. These results showed that the influence of salinity on the development of necrosis in hybrid genotypes thus favored their sensitivity to $P$. megakarya. Furthermore, these results showed that the hybrid genotypes of the F79SB progeny exhibiting better tolerance under sodium and saline stress are the hybrid genotypes F79SB3, F79SB4, F79SB5, F79SB8 and F79SB15 with small necrotic surfaces according to the different concentrations. They can be multiplied by cloning and made available to farmers in regions with high salinity for an improvement in yield in cocoa plantations.

\section{Conflict of interest statement}

Authors declare that they have no conflict of interest.

\section{Acknowledgement}

Authors would like to thank the Dean of the Faculty of Science of the University of Douala for allowing this research work to be done in the nursery and the laboratory of Plant Biology.

\section{References}

Almeida, P., de Boer, G., de Boer, A.H., 2014. Differences in shoot $\mathrm{Na}+$ accumulation between two tomatoes species are due to differences in ion affinity HKT1;2. J. Plant Physiol. 171, 438-447.

Anushka, M.W., Dunwell, J.M., 2018. Cacao biotechnology: current status and future prospects. Plant Biot. J. 16, 4-17.

Babu, M.A., Singh, D., Gothandam, K.M., 2012. The effect of salinity of growth, hormone and mineral elements in leaf and fruit of tomato cultivar PKM1. T. Anim. Plant Sci. 22, 159-164.

Blaha, G., Lotode, R., 1976. Un caractère primordial de sélection du cacaoyer au Cameroun: la résistance à la pourriture brune des cabosses, Café Cacao Thé. 20 (2), 97-116.

Boukharta, N., Ennaffah, B., Ouazzani, B., Ouazzani, T.A., Benkirane, R., Douira, A., 2012.
Effet de la salinité sur la sensibilité de la tomate à la verticilliose. Bull. Soc. Roy. Sci. Liè. $81,75-81$.

Cilas, C., Ndounbé-Nkeng, M., Bidzanga, N., N'goran, J., 2004. Incidence de la maladie et de résistance sur le terrain. Dans : Cilas C. et Despréaux D. (Eds.). Amélioration de la résistance des arbres de cacao à la maladie de Phytophthora. Repères, CIRAD, Paris, France, 23p.

Despréaux, D., Clement, D., Patriot, M., 1989. La Pourriture Brune Des Cabosses Du Cacaoyer $\mathrm{Au}$ Cameroun; Mise En Evidence D'un Caractère De Résistance Au Champ. Agron. 9, 683-691.

Djerroudi, O., Bissati, S., Belkhodja, M., 2011. Biochemical responses of two Atriplex species (Atriplex alinus L. and Atriplex canescens (Purch) Nutt) under salt stress conditions. Int. J. Plant Physiol. Bioch. 3(10), 163-168.

Djocgoue, P.F., Boudjeko, T., Nankeu, D.J., Efombagn, M.I.B., Nyassé, S., Omokolo, D.N., 2006. Comparative assessment of the resistance of Cocoa (Theobroma cacao L.) progenies from SNK10 x SNK413; ICS84 x ICS95 to Phytophthora megakarya in Cameroon by measuring size of necrotic lesion along the midrib. Plant Pathol. J. 5, 329-333.

Djocgoue, P.F., Simo, C., Mbouobda, H.D., Boudjeko, T., Nankeu, D.J. Omokolo, N.D., 2010. Assessment and heritability of productivity and tolerance level to Phytophthora megakarya in two hybrid populations of Theobroma cacao. J. Plant Pathol. 92, 607-617.

Effa, P.O., Jude, M.N., Martine, L.O., Jules, C.D.K., Pierre, F.D., 2017. Virulence Test of Some Phytophthora megakarya Isolates on Cocoa (Theobroma cacao L.) Hybrid Pods. IOSR J. Biotechnol. Bioch. 3(1), 73-81.

Efombagn, M. I. B., Bieysse, D., Nyassé, S., Eskes, A.B., 2011. Selection for resistance to Phytophthora pod rot of cocoa (Theobroma cacao L.) in Cameroon: Repeatability and reliability of screening tests and field observations. Crop Prot. 30, 105-110.

Erashan, F., Inal, A., Gunes, A., Alpaslan, M., Atikmen, N.C., 2015. Comparative physiological and growth responses of tomato pepper plants to fertilizer induced salinity and salt stress. Fres. Environ. Bull. 24 (5A), 17741778. 
Gupta, B., Huang, B., 2014. Mechanism of salinity tolerance in plants ; physiological, biochemical and molecular chariterization. Int. J. Gen. 2014:701596. doi: 10.1155/2014/701596. Epub 2014 Apr 3, 1-18.

Janny, G.M.V., Barbara, J.R., Julie, F., 2003. A la découverte du cacao, un guide pour la formation des facilitateurs. CABI Biosci. $114 \mathrm{p}$.

Koudjega, T., Tossah, B.K., 2009. Improvement of soils fertility management in cocoa plantations in Togo. Proceeding of the 7 th international symposium on plant-soil interactions at low pH. 17-21 may, Guangzhou, China, pp. 184-185.

Medja, D.R., Admed, S., Hedia, B.O., Mohsen, M., Bouzid, N., 2009. Salinity effect on Fusarium Wilt severity and Tomato growth. Dyn. Soil Dyn. Plant. 3(1), 61-69.

Minyaka, E., Madina, B.C.V., Kusznierewicz, B., Oumar, D., Haouni, S., Hawadak, J., Niemenak, N., Omokolo, N. D., 2018. Effect of $\mathrm{MgSO}_{4}$ nutrition on Theobroma cacao L. susceptibility to Phytophtora megakarya infection. Plant Protec. Sci. 54 (2), 74 - 82.

Minyaka, E., Simo, C., Kusznierewicz, B., Madina B.C.V., Mouen, P.J.C., Niemenak, N., Omokolo, N.D., 2017. Flavones in Cocoa Defence against Phytophthora megakarya. J. Botan. Sci. 6(3), 50-63.

Mohameden, O.M., Driss, B., Ali, O.M., 2011. Etude de l'effect du stress salin $(\mathrm{NaCl})$ chez deux varietés de tomate (Campbell 33 et Mongal). Int. J. Biol. Chem. Sci. 5(3), 890-900.

Morrissey, J., Stack Conrad, J., Valls, R., Motamayor, C.J., 2019. Low-cost assembly of a cacao crop genome is able to resolve complex heterozygous bubbles. Hort Res. 6 (44), 16-13.

Ndoumbé-Nkeng, M., Cilas, C., Myuemb, E., Nyassé, S., Bieysse, D., Flori, A., Sache, I., 2004. Impact of removing diseased pods on cocoa black pods cause by Phytophthora megakarya and on cocaoa production in Cameroon. Crop prot. 23, 415-424.

Nouck, A.E., Taffouo, V.D., Tsoata, E., Dibong, S.D., Nguemezi, S.T., Gouado, I., Youmbi, E., 2016. Growth, Biochemical Constituents, Micronutrient Uptake and Yield Response of Six Tomato (Lycopersicum esculentum L.). J. Agron. 15, 58-67.

Nyadanu, D., Akromah, R., Adomako, B., Kwoseh, C., Dzahini-Obiatey, H., Lowor, S.T., Akrofi, A.Y., Assuah, M.K., 2012. Host plant resistance to Phytophthora pod rot in cocoa (Theobroma cacao L.): The role of epicuticular wax on pod and leaf surfaces. Int. J. Bot. 8(1), 13-21.

Nyadanu, D., Akromah, R., Adomako, C., Kwosh, S.T., Lowor, H., Dzahini-Obiatey, A.Y., Akrofi, F., Owusu, A., Opoku, Y.A., Assuah, M.K., 2013. Phytochemical mechanisms of resistance to black pod disease in cocoa (Theobroma cacao L.). Amer. J. Bioch. Mol. Biol. 3(1), 2037.

Nyassé, S., (1997). Etude de la diversité de Phytophthora megakarya et caractérisation de la résistance du cacaoyer (Theobroma cacao L.) à cet agent pathogène. Thèse Ph.D., Institut National Polytechnique, Toulouse, France, $160 p$.

Nyassé, S., Despréaux, D., Cilas, C., 2002. Validity of a leaf inoculation test to assess the resistance to Phytophthora megakarya in cocoa (Theobroma cacao L.) diallel mating design. Euphytica. 123, 395-399.

Nyassé, S., Cilas, C., Herail, C., Blaha, G., 1995. Leaf inoculations as an early screening test for cocoa (Theobroma cacao L.) resistance to Phytophthora black pod disease. Crop Prot. 14, 657-663.

Nyassé, S., Efombagn, M.I.B., Bouambi, E., Ndoumbe-Nkeng, M., Eskes, A.B., 2003. Early selection for resistance to Phytophthora megakarya in local and introduced cocoa varieties in Cameroon. Trop. Sci. 43, 96e102.

Ondobo, M.L., Effa O.P., Djocgoue, P.F., Manga, N.J., Boudjeko, T., Omokolo, N.D., 2014. Phenolic content and heritability of resistance in four hybrid populations of Theobroma cacao L. after Leaves inoculation with Phytophthora megakarya Bras. and Grif. Int. J. Biol. Chem. Sci. 8 (1), 17-30.

Ondobo, L.M., Effa, O.P., Manga, N.J., Djoko, K.C.J., Djocgoue, F.P., 2017. Breeding of parental and tolerant hybrids of Theobroma cacao L. to Phytophthora megakarya Bras. and Griff. Int. J. Plant Physiol. Biochem. 9(2), 9-21.

Ploetz Randy, C., 2007. Les maladies du cacao : une menace importante pour la production de chocolat dans le monde. Phytopathol. 97 (12), 1634-163.

Pokou, N.D., Fister, S.A., Winters, N., Tahi, M., Klotioloma, C., Sebastian, A., Marden, H.J., Maximova, N.S., Guiltinan, J.M., 2019. Resistant and susceptible cacao genotypes exhibit defense gene polymorphism and unique 
early responses to Phytophthora megakarya inoculation. Plant Mol. Biol. 99, 499-516.

Pokou, N.D., N'goran, J.A.K., Kébé, I., Eskes, A., Tahi, M., Sangaré, A., 2008. Levels of resistance to Phytophthora pod rot in cocoa accessions selected on-farm in Côte d'Ivoire. Crop Prot. 27, 302-309.

Regragui, A., Rahouti, M., Lahlou, H., 2003. Effet $\mathrm{du}$ stress salin sur Verticillium albo-atrum: pathogénécité et production d'enzymes cellulolytiques in vitro. Cryptogamie Mycol. (2), 167-174.

Ruiz-Lazano, J.M., Porcel, R., Azcon, C., Aroca, R., 2012. Regulation by arbuscular micorrhizae of the integrated physiological response to salinity in plants: new challenges in physiological and molecular studies. J. Exp. Bot. 63(11) : 40334044 .

Shabala, S., Rana, M., 2012. Salinity stress: physiological constraints and adaptative mechanisms. Plant Stress Physiol. 1(1), 59-93.
Taffouo, V.D., Djiotie, N.L., Kenne, M., Din, N., Priso, J.R., Dibong, S.D., Amougou, A., 2008. Effects on salt stress on physiological and agronomic characteristics of three tropical cucurbit species. J. Appl. Biosci. 10, 434-441.

Taffouo, V. D., Ngwene, B., Amougou, A., Franken, P., 2014. Influence of phosphorus application and arbuscular mycorrhizal inoculation on growth, foliar nitrogen mobilization, and phosphorus partitioning in cowpea plants. Mycorrhiza. 24(5), 361-8.

Wacquant, J.P., 1974. Research on cation roots properties uptake. Physiological and ecological role. Ph.D., thesis, University of Montpellier, France, $155 \mathrm{p}$.

Zörb, C., Schmitt, S., Neeb, A., Karl, S., Linder, M., Schubert, S., 2004. The biochemical reaction of maize (Zea mays L.) to salt stress is characterized by a mitigation of symptoms and not by a specific adaptation. Plant Sci. 167, 91100.

\section{How to cite this article:}

Simo, C., Tchiaze, I. A. V., Tchouakeu, E. N., Njonzo-nzo, S. A., Tassong, S. D., Djocgoue, P. F., Niemenak, N., Taffouo, V. D., 2020. Influence of salinity on the incidence and severity of Phytophthora megakarya in a hybrid family of Theobroma cacao L. Int. J. Curr. Res. Biosci. Plant Biol. 7(1), 1-16.

doi: https://doi.org/10.20546/ijcrbp.2020.701.001 